\title{
Taxonomy and distribution of the pikas (Ochotona, Lagomorpha) of alpina-hyperborea group in North-East China and adjacent territories
}

\author{
Andrey A. Lissovsky, Qisen Yang \& Alexander E. Pil'nikov
}

\begin{abstract}
Pikas from Manchurian region were studied using craniometric, bioacoustical, and genetic features. The study revealed that southeast Transbaikalia and northern Manchuria are inhabited by only one taxon of the species level - Ochotona mantchurica Thomas, 1909. The name cinereofusca should be allocated to a form of $O$. hyperborea from the left bank of Shilka River. The taxon coreana does not belong either to $O$. mantchurica or $O$. hyperborea, and, probably, should be recognized as a separate species $O$. coreana Allen \& Andrews, 1913.
\end{abstract}

KEY WORDS: Taxonomy, distribution, pikas, alpina-hyperborea, Ochotona, mantchurica, coreana, scorodumovi, cinereofusca.

Andrey A. Lissovsky [andlis@zmmu.msu.ru], Zoological Museum of Moscov State University, Bolshaya Nikitskaya ul. 6, Moscow 125009, Russia; Qisen Yang [yangqs@ioz.ac.cn], Institute of Zoology, Chinese Academy of Sciences, B5 Datun Road, Beijing 100101, China; Alexander E. Pil'nikov [rim@krasnokamensk.ru], Chitinskaya antiplague station, Chitinskaya oblast, Krasnokamensk-3, 107/14, 674673, Russia.

\section{Систематика и распространение пищух (Ochotona, Lagomorpha) группы alpina-hyperborea в Северо-Восточном Китае и прилежащих территориях}

\begin{abstract}
А.А. Лисовский, Ч. Ян, А.Э. Пильников
РЕЗЮМЕ. Исследованы пищухи манчжурского региона, с использованием краниометрических, биоакустических и генетических признаков. Показано, что юго-восточное Забайкалье и северную Манчжурию населяет один таксон видового ранга — Ochotona mantchurica Thomas, 1909. Название cinereofusca принадлежит форме Ochotona hyperborea с северного берега Шилки. Форма coreana не входит ни в состав $O$. mantchurica ни $O$. hyperborea и, вероятно, должна быть выделена в самостоятельный вид O. coreana Allen \& Andrews, 1913.
\end{abstract}

КЛЮЧЕВЫЕ СЛОВА: Систематика, распространение, пищухи, alpina-hyperborea, Ochotona mantchurica, coreana, scorodumovi, cinereofusca.

\section{Introduction}

The taxonomy and distribution of pikas of alpinahyperborea group were studied extensively during last years (Lissovsky, 2003, 2005; Lissovsky et al., 2007). However, the China remains a blank spot yet in this respect. There is a tangle of races inhabiting Manchuria and adjacent territories of Korea and Transbaikalia, which taxonomical assessment and names remain not clearly established.

The following nominal taxa of pikas were described from Manchuria: cinereofusca Schrenk, 1858 from the upper Amur River; mantchurica Thomas, 1909 from the pass of the Chinese Eastern Railway through the Great Khingan Mountains; coreana Allen \& Andrews, 1913 from the north of Korea; and scorodumovi Skalon, 1935 from the upper Argun' River, surroundings of Kailastuy village. The name cinereofusca is usually applied to the pikas inhabiting the lands south of Shilka
River (Feng \& Zheng, 1985; Smith et al., 1990; Niu et al., 2001; Hoffmann \& Smith, 2005). This name is sometimes applied also to some pika populations from Manchuria (Feng \& Zheng, 1985; Niu et al., 2001). At the same time, the pikas living to the south of Shilka River are commonly referred to $O$. alpina scorodumovi in the Russian literature (Ognev, 1940; Yakhontov \& Formozov, 1992; Sokolov et al., 1994). Yakhontov \& Formozov (1992) expressed the opinion that the name cinereofusca should be applied to the subspecies of northern pika $O$. hyperborea (Pallas, 1811). Pikas from Greater and Lesser Khingan Mountains are most often named O. hyperborea mantchurica (Smith et al., 1990; Sokolov et al., 1994; Hoffmann \& Smith, 2005), although they are called sometimes $O$. alpina cinereofus$c a$. Pikas from the Northern Korea are traditionally named $O$. hyperborea coreana. There were not any special taxonomic revisions or published arguments in favor of applying of one or another name to the alpina- 
hyperborea pikas distributed in the region under consideration.

Craniometric study of representatives of the alpinahyperborea group as a whole (Lissovsky, 2003) revealed that the pikas from southeast Transbaikalia (area between Shilka and Argun' rivers) and Manchuria do not fit within variation of the two principal species of the group - O. alpina and O. hyperborea. Subsequent bioacoustical study (Lissovsky, 2005) revealed that the structure of acoustic signals of some specimens from the southeast Transbaikalia and from the north of Greater Khingan is identical and can be easily discriminated from the one known for other representatives of alpinahyperborea group due to the presence of two independent sources of signals production in the acoustic channel. The only one species which range is adjacent with the discussed territory, O. hyperborea, is specific by some qualitative characters of the shape of the timeand-frequency modulation curve in the alarm calls. Besides, acoustic repertoire of $O$. hyperborea contains common particular deep modulated song elements, which are absent in pikas from southeast Transbaikalia and Manchuria. The genetic study confirmed taxonomic proximity of the pikas inhabiting southeast Transbaikalia and the north of Lesser Khingan Mountains (Lissovsky et al., 2007).

The aim of this study is to analyze the morphometric variation of the pikas of Manchurian region, including the topotypical populations of the nominal taxa, and to specify taxonomical position of the pikas from Manchuria.

\section{Materials and Methods}

The sample of 864 intact skulls of adult pikas was used in order to examine the individual and intersample distribution of the representatives of alpina-hyperborea group. The sample contains 507 skulls of O. hyperborea, 224 skulls of O. alpina, 62 skulls of $O$. turuchanensis, 70 skulls of the races mantchurica and scorodumovi and one skull of pika from coreana race. The specimens used in this study were identified using the morphological characters proposed by Lissovsky (2003a, b). Eleven measurements were taken (with accuracy of $0.1 \mathrm{~mm}$ ) from each skull as follows: condylobasal length, length and width of palatine foramen, length of the bone ledge separating incisive and palatine foramina, diastemal length, alveolar length of maxillary toothrow, rostral length (from the anterior edge of premaxillary bones to the posterior edge of maxillary toothrow alveoli), zygomatic breadth, postorbital constriction, maximal width between lateral edges of auditory bullae, and skull height. All measurements were normalized by variance for the sake of correctness of statistical analyses.

The studied specimens are housed in the Zoological Museum of Moscow State University (ZMMU), Zoological Institute of the Russian Academy of Sciences, St. Petersburg (ZIN), Irkutsk State University (IGU),
Museum für Naturkunde, Berlin (MNB), Institute of Systematics and Ecology of Animals of the Siberian Branch of the Russian Academy of Sciences, Novosibirsk (ISEA), Far East State University, Vladivostok (FEU), Tomsk State University (TGU), Geographical Faculty of Moscow State University (GFMU), College of Wildlife of the Northeast Forestry University, Harbin (HCW), State Darwin Museum, Moscow, personal collections of N.D. Ovodov (Krasnoyarsk) and G.À. Voronov (Yuzhno-Sakhalinsk).

The localities from which the pikas are known in southeast Transbaikalia and Manchuria are shown in Fig. 1. The sample sizes and the museums where the specimens are kept are indicated in the Appendix.

The skull measurements were collected during a long time in a number of museums. When it became obvious (Lissovsky, 2003à) that existing set of measurements is insufficient for determination of pikas from Manchuria, the additional measurements were taken from the same skulls. These measurements are: maximal length of orbit, maximal width of orbit, maximal length of auditory bulla, interorbital constriction, height of mandible, and width of processus articularis near coronoid protuberance. We were unable take additional measurements in several museums, so these measurements were included only in analysis of the distribution of pikas from southeast Transbaikalia and Manchuria $(n=55)$ and northern pikas from the Amur River basin and adjacent territories (Hentiyn Nuruu Range, Hentiyn-Chikoy Mountains and Yablonovyii Range, northeast Transbaikalia, Stanovoy Range and the basins of Zeya and Bureya rivers, Sikhote-Alin Range, Sakhalin Island) $(n=67)$. All measurements were performed by AL. The canonical analysis of pikas from southeast Transbaikalia, Manchuria, Amur River basin, and adjacent territories were performed using samples with more than six individuals as a grouping variable.

A preliminary analysis revealed a high value of mandible height for discrimination of pikas from the banks of Amur River. Because the manner of taking this measure is quite strictly fixed we assume that measurements taken by different people would not contain a significant error. Therefore the mandible height of the adult specimens from coreana sample from vicinities of Fusong town $(n=32)$ from the Institute of Zoology of the Chinese Academy of Sciences (IOZ) was measured by Yang.

Intersample distribution was studied on the basis of the samples including not less than four specimens. Each sample included the specimens collected in the same strictly defined locality.

All calculations were performed in modules Basic Statistics and Tables, General discriminant analysis, and Principal Components, and Classification Analysis in Statistica 6 (StatSoft 2001).

Bioacoustical study was carried out on the basis of the sample of 1131 calls of 112 pikas of mantchurica and scorodumovi races, and 16 calls of three specimens of $O$. hyperborea from Shilka River. We had the fol- 


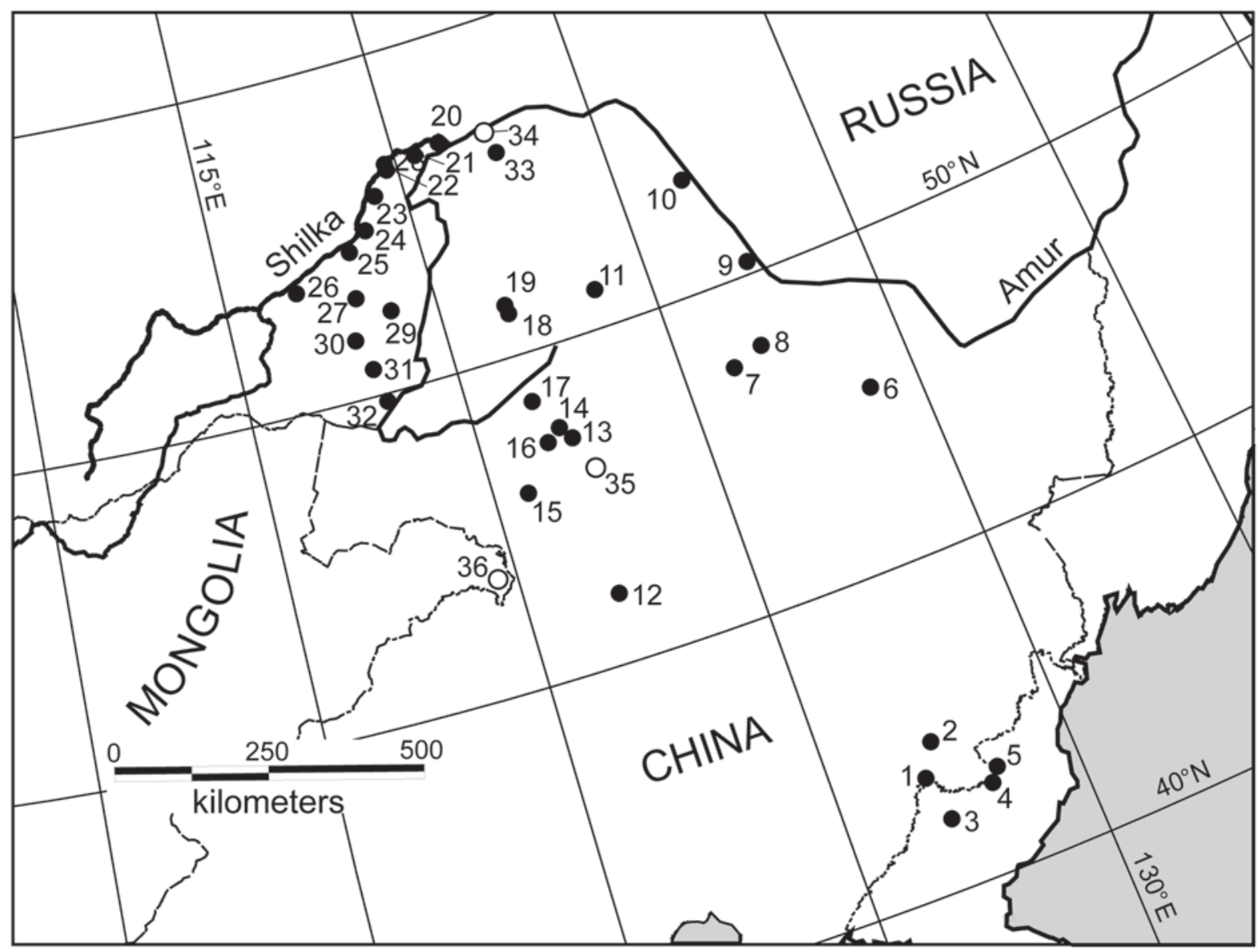

Figure 1. The scheme of distribution of pikas in Manchurian region. Filled circles correspond to museum specimens, open circles - to other kind of data. Explanations of numbers see in Appendix.

lowing material from southeast Transbaikalia and Manchuria (the first figure is the number of the analyzed calls and the figure in brackets is the number of specimens): China, Inner Mongolia, Bukhedu town 131 (8); China, Inner Mongolia, Genhe town 7 (3); Russia, Chita Region, Krasnokamensk District, near Kailastuy village, Bolshoy Chir Mountain 12 (2); Chita Region, Kalga District, near Kozlovo village 234 (11); Chita Region, Alexandrovskii Zavod District, upper Ker-Khira River 484 (41); Chita Region, Sretensk District, right bank of the Shilka River opposite Lomy village (372 $\mathrm{km}$ from the mouth of Shilka River) 58 (11); Chita Region, Sretensk District, right bank of the Shilka River opposite Firsovo village (358 km from the mouth of Shilka River) 4 (1); Chita Region, Sretensk District, right bank of the Shilka River Chachakan River (353 $\mathrm{km}$ from the mouth of Shilka River) 9 (2); Chita Region, Sretensk District, right bank of the Shilka River opposite Uktycha village $(348 \mathrm{~km}$ from the mouth of Shilka River) 12 (3); Chita Region, Sretensk District, right bank of the Shilka River $3 \mathrm{~km}$ downstream the Uktycha village 8 (1); Chita Region, Sretensk District, right bank of the Shilka River Bolshaya Uleygicha River (214 km from the mouth of Shilka River) 4 (1);
Chita Region, Sretensk District, right bank of the Shilka River opposite Ust-Chernaya village ( $249 \mathrm{~km}$ from the mouth of Shilka River) 99 (16); Chita Region, Mogocha District, right bank of the Shilka River near mouth of Dzheltuga River (167 km from the mouth of Shilka River) 25 (4), Chita Region, Mogocha District, right bank of the Shilka River (119 km from the mouth of Shilka River) 22 (2); Chita Region, Mogocha District, right bank of the Shilka River (113 km from the mouth of Shilka River) 17 (4); Chita Region, Mogocha District, right bank of the Shilka River $(101 \mathrm{~km}$ from the mouth of Shilka River) 5 (2). The material was collected during the 2003-2007 field seasons. All records are kept in the Zoological Museum of Moscow State University.

Because the previous investigation showed that qualitative characters make a greater contribution in discrimination of $O$. hyperborea with races mantchurica and scorodumovi than the quantitative ones (Lissovsky, 2005), we refused to provide quantitative comparison of the frequency modulation curves' shapes. The absence or presence of deep modulated elements of songs or synchronous biphonations in the repertoire was used for identification of specimens by their calls. 


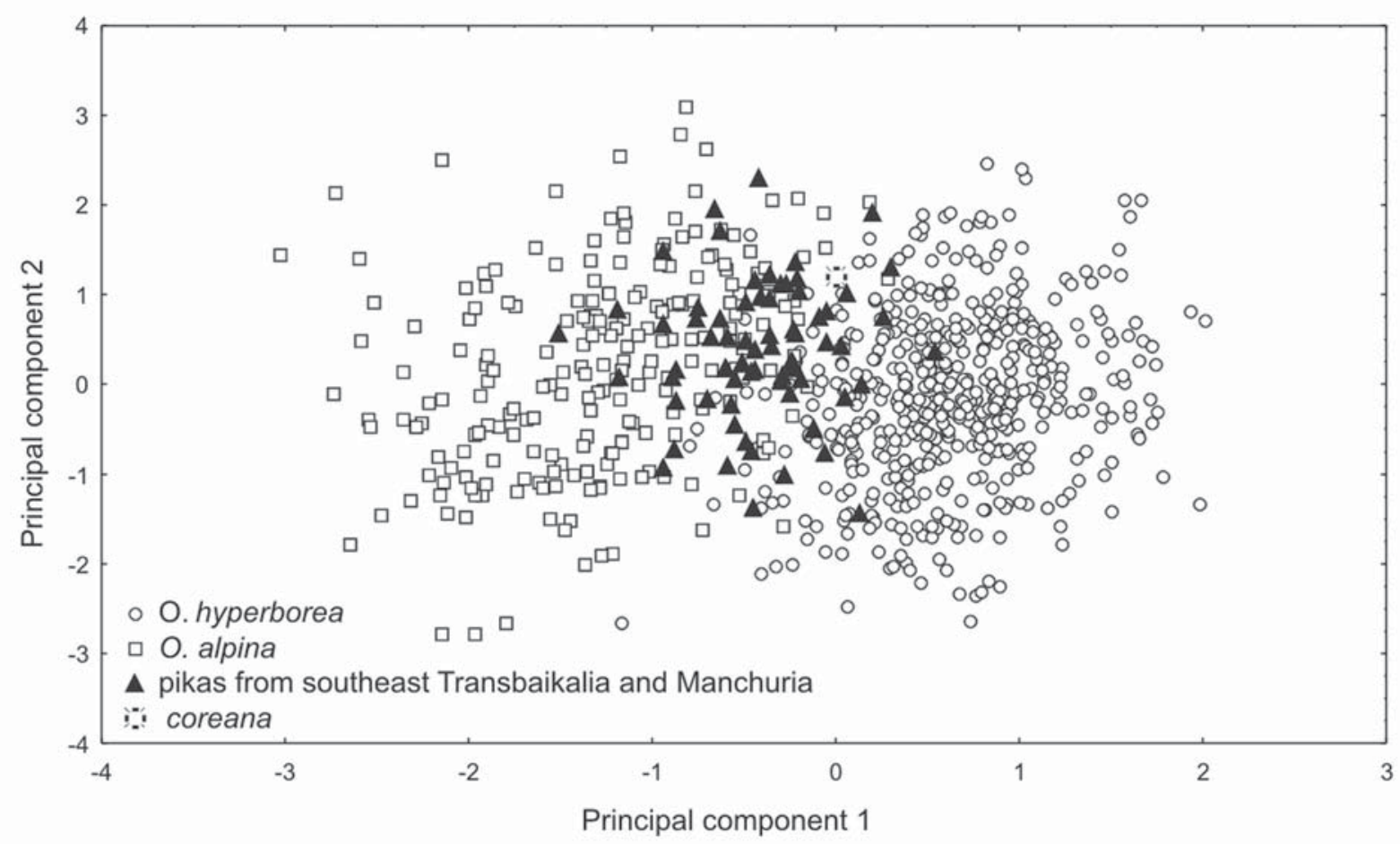

Figure 2. Distribution of pikas specimens from alpina-hyperborea group based on the principal component analysis of skull measurements.

Specimens used for molecular analysis are listed in Appendix. The full gene cytochrome b (1140 bp) was sequenced for all the specimens except EF567060, EF567061 and DQ347449. Fragment of the $330 \mathrm{bp}$ (from 196 to 525 position from the beginning of the gene) was sequenced for EF567060 and EF567061, one fragment (DQ347449) of the 683 bp was taken from GeneBank.

The total genomic DNA from ethanol-preserved tissue was extracted using standard phenol-chloroform method. The DNA from dry skins were extracted using Wizard SV96 Genomic DNA Purification System (Promega, Madison, WI, USA) following manufacturer instructions.

The full cytb was amplified using primers L14724 of Yu et al. (2000) and original primer H15913 (ACTTCATTTTTCGTTTACAAGACCA). The short fragment of coreana was amplified using primers L14944 and $\mathrm{H} 15274$ of $\mathrm{Yu}$ et al. (2000). PCR protocol was accepted according to Yu et al. (2000). The sequencing was performed using all these four primers. Sequences were assembled in SeqMan v. 5.06 (DNASTAR Inc) and manually edited.

The tree-building algorithms employed in this study were maximum parsimony and maximum likelihood. Unweighted maximum parsimony analysis employing heuristic search with simple stepwise sequences addition and tree-bisection-reconnection branch swapping was performed in PAUP*. The branch support was calculated in the same program based on 500 nonparametric bootstrap replicates.
Maximum-likelihood analysis was performed in Treefinder (Jobb, 2005). The maximum-likelihood model of DNA evolution was estimated separately for each of the three codon positions. The type of substitution model was taken according the previous publication (Lissovsky et al., 2007). A maximum-likelihood bootstrap support was based on 500 replicates with the same models parameters as in tree search.

Each analysis was performed twice: on the basis of the full gene and on the basis of the part corresponding to coreana sequence. The latter was due to the need to evaluate the place of coreana on the tree, avoiding a bias inducting by a short fragment length.

\section{Results}

The specimens from the area between Shilka and Argun' rivers and from Greater and Lesser Khingan mountains form a homogeneous group in the space of morphological features (Fig. 2). The distribution of these specimens in the axes of first two principal components (explaining $90 \%$ of total variance) does not differ from the normal distribution significantly (ChiSquare $=2.93, \mathrm{df}=3, \mathrm{p}=0.40$ and Chi-Square $=4.18, \mathrm{df}=3$, $\mathrm{p}=0.24$, for the first and second principal components respectively). The distribution of centroids of geographical samples also tends to aggregate. Samples of the races under consideration are located between those of $O$. alpina and $O$. hyperborea in the hyperspace of principal components extracted from morphological features (Fig. 3). 


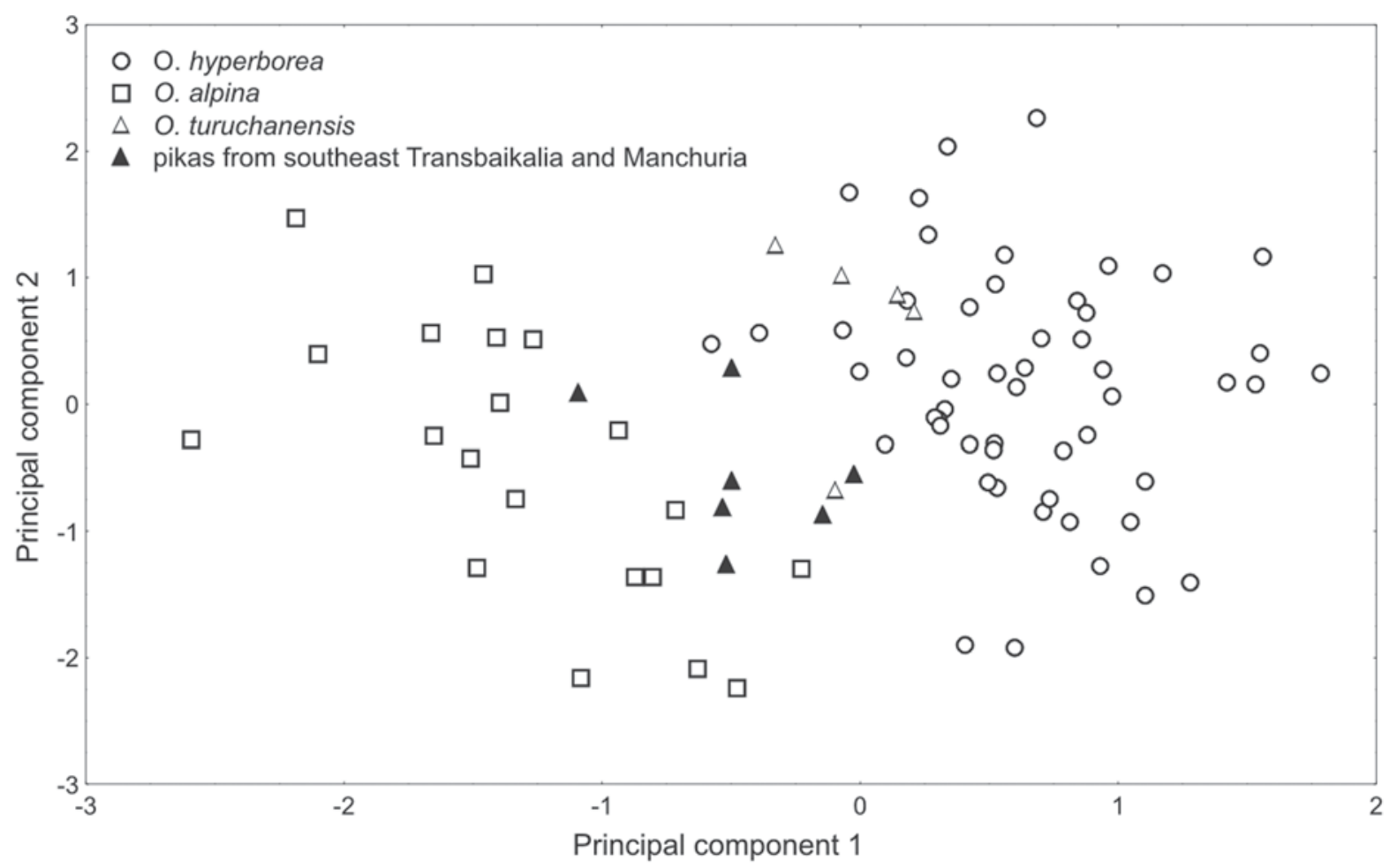

Figure 3. Distribution of pikas samples from alpina-hyperborea group based on the principal component analysis of skull measurements.

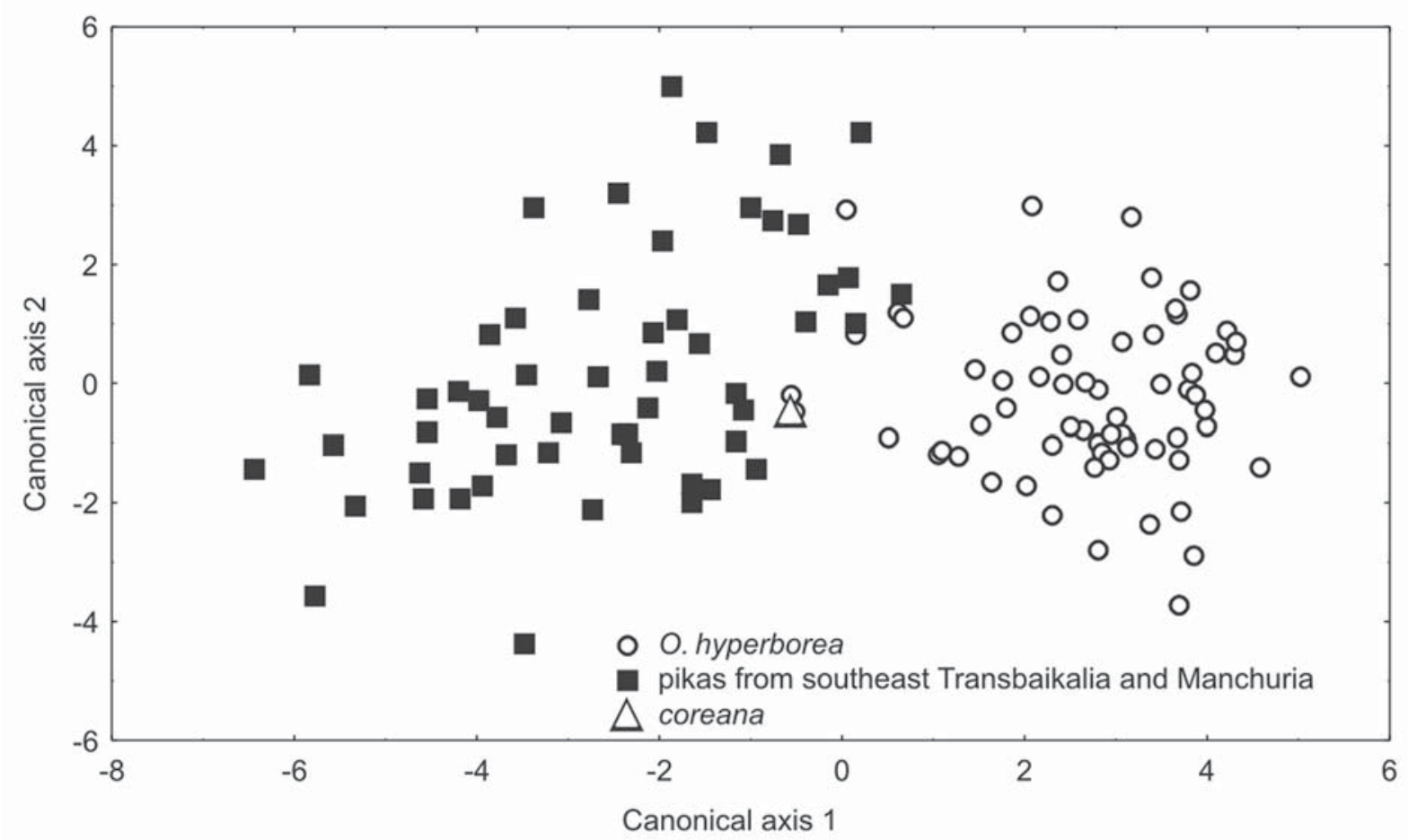

Figure 4. Distribution of pikas specimens from Amur region on the flat of the two first canonical axes, calculated on the basis of the skull measurements. 


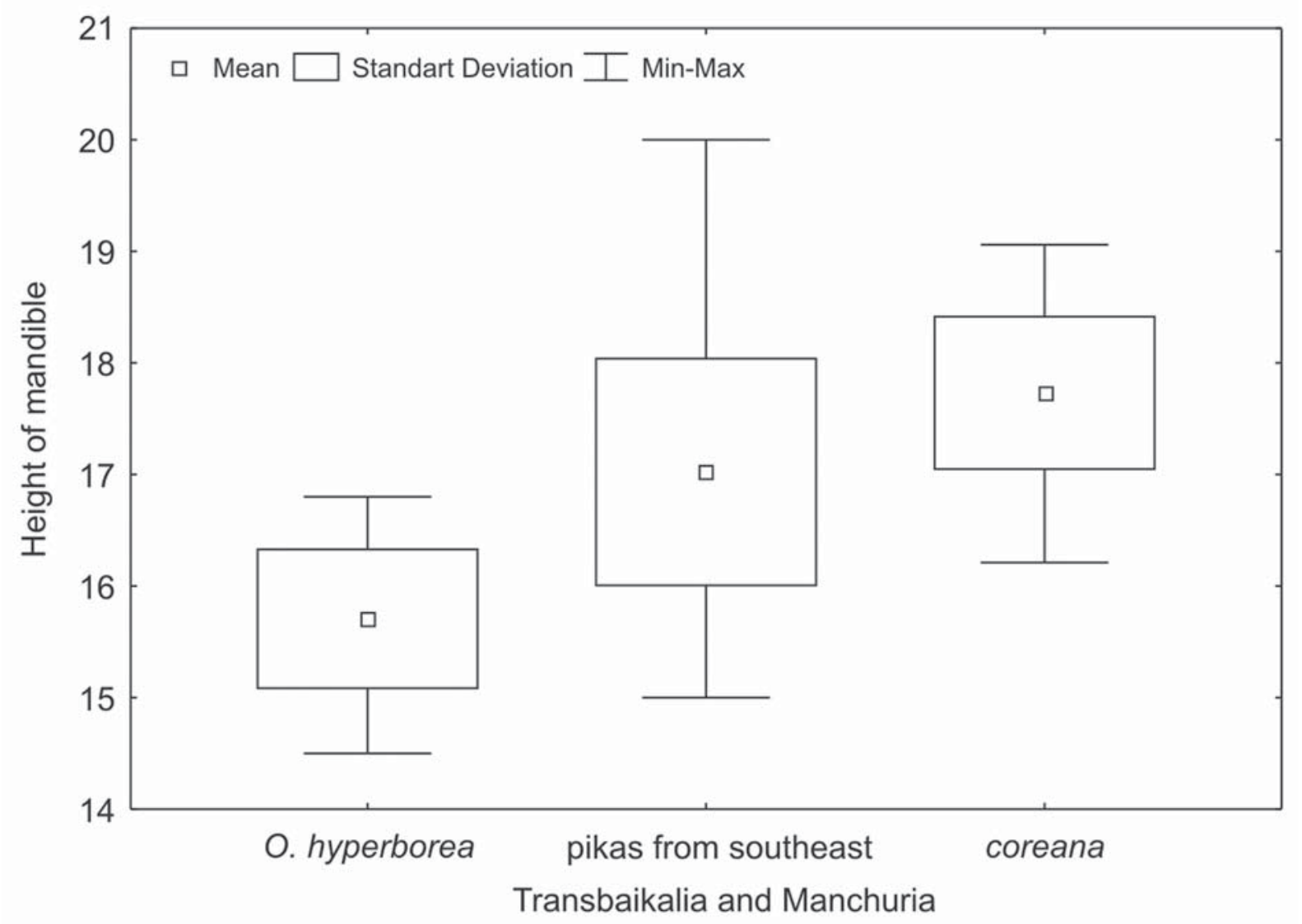

Figure 5. Distribution of values of the mandible height in pikas from Amur region.

Pikas from southeast Transbaikalia and Manchuria just marginally overlap with the specimens of O. hyperborea from Amur River basin and adjacent territories on the flat of two first canonical axes (Fig. 4). However, the skull size (condilobasal length) is widely overlapped between representatives of these two groups: $37.2-47.8$ $\mathrm{mm}$, on average $41.7 \mathrm{~mm}$ in "manchurian" pikas and 35.6-41.2 $\mathrm{mm}$, on average $37.7 \mathrm{~mm}$ in O. hyperborea.

The only complete skull of coreana included in this analysis is located within the range of pikas from southeast Transbaikalia and Manchuria (Figs 2-4). At the same time it falls into the overlapping area with $O$. hyperborea. Nevertheless zone of overlapping by the values of the mandible height between $O$. hyperborea and coreana is quite small (Fig. 5).

All the calls of pikas recorded from Shilka River, Ker-Khira River, Kozlovo village, Kailastuy village, Bukhedu town, Genhe town turned out to be of the same kind and completely fall into variation of scorodumovi (Lissovsky, 2005; Fig. 6). Particularly the complicated spectral structure of calls induced by biphonations was common in all localities. We did not find any deep modulated calls which are characteristic for O. hyperborea.

The topology of all trees obtained using different algorithms was similar (Figs. 7 and 8). Specimens from
Shilka River, from Kailastuy and from Lesser Khingan form the monophyletic group, which is a sister group to $O$. hyperborea. The p-distance between specimen from Lesser Khingan and topotype of scorodumovi is $1.3 \%$. Average p-distance between haplotypes of pikas from southeast Transbaikalia and Manchuria and O. hyperborea is $6.7 \%$. Two specimens of coreana race are identical in the nucleotide sequence. Korean pikas form a basal group relative to the alpina-hyperborea unit, although this branch has a low bootstrap support. In the analysis based on the full gene, the Korean pikas are branching out on the tree above the pikas from southeast Transbaikalia and Manchuria and O. hyperborea, and this branching pattern has a high bootstrap support. In the analysis based on the part of the gene, all four clades of alpina-hyperborea group branched out from the same tree node (Figs. 7 and 8). In this case, support of alpina-hyperborea group is not high (51-60) when compared with $O$. pallasi. Support of alpina-hyperborea group excluding coreana can be considered nearly satisfactory (64) only in maximum likelihood analysis. However in the parsimony analysis, based on the part of the gene, corresponding to known coreana' fragment, but without coreana (tree is not shown), support of alpina-hyperborea group was 81 . Average p-distance between haplotypes of coreana and pikas from south- 


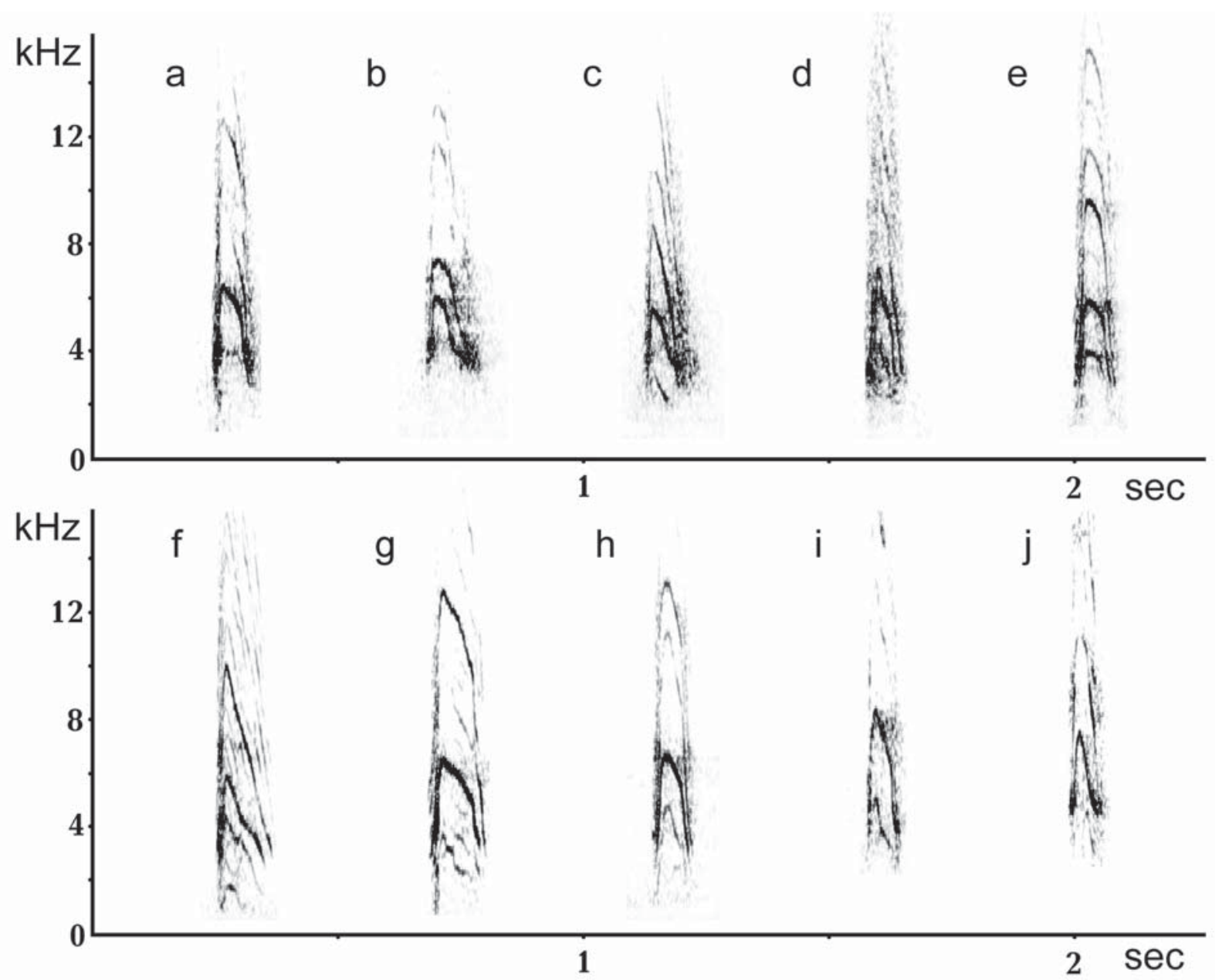

Figure 6. The sonograms of alarm calls of pikas from southeast Transbaikalia and Manchuria. a, b, c - different localities from the Shilka River; d - Kailastuy; e - Ker-Khira River; f, g-Kozlovo; h — Genhe; i, j — Bukhedu.

east Transbaikalia and Manchuria is $9.2 \%$, O. hyperborea-9.3\%,O. alpina-9.8\%,O. turuchanensis $9.5 \%$, o. pallasi $-10.8 \%$. At the same time average $\mathrm{p}$ distance between $O$. hyperborea and $O$. alpina is $8.5 \%$.

\section{Clarifying the Type Localities}

It is necessary to specify more precisely the terra typica for the taxa mantchurica, coreana, and cinereofusca before the discussion of their taxonomy and nomenclature. Original identification of the type localities for these taxa cannot be located on the modern maps (coreana) or they were not clear delineated (mantchurica and cinereofusca). This makes problematic classification of the recently collected specimens as the topotypes, especially when the type material is lacking.

Terra typica of mantchurica according to the original description is "Khingan" (Thomas, 1909: 504). However there is a more precise indication to the collecting locality on the first page of the Thomas' publication: "in the Khingan Mountains, at about an altitude of 3800 feet, at the point where the Siberian Railway cuts the range" (Thomas, 1909: 500). The holotype was collected 18 May 1908 and kept in Natural History Museum, London. Chinese Eastern Railway "cuts the range" between railway stations Xinggan and Bukhedu (Bugt). The above altitude of 3800 feet is exactly the altitude of that range through which the tunnel of the railway between Xinggan and Bukhedu is built. Therefore the part of the Greater Khingan Range between railway stations Xinggan and Bukhedu is suggested here to be considered the terra typica of the nominal taxon O. hyperborea mantchurica Thomas, 1909.

Terra typica of coreana according to the original description is "Pochong" (Allen \& Andrews, 1913: 429). We were unable to find such a geographic name on the modern maps available to us. But the route described and collecting dates given for several other mammals in cited publication allow to ascertain that the pika specimens were collected in the south part of Changbai Shan (to the south of Pai T'ou Shan volcano), just east of Yalujiang River valley. This locality is named as Poch'on-up on the modern maps (128.297 E, $41.519 \mathrm{~N})$. 


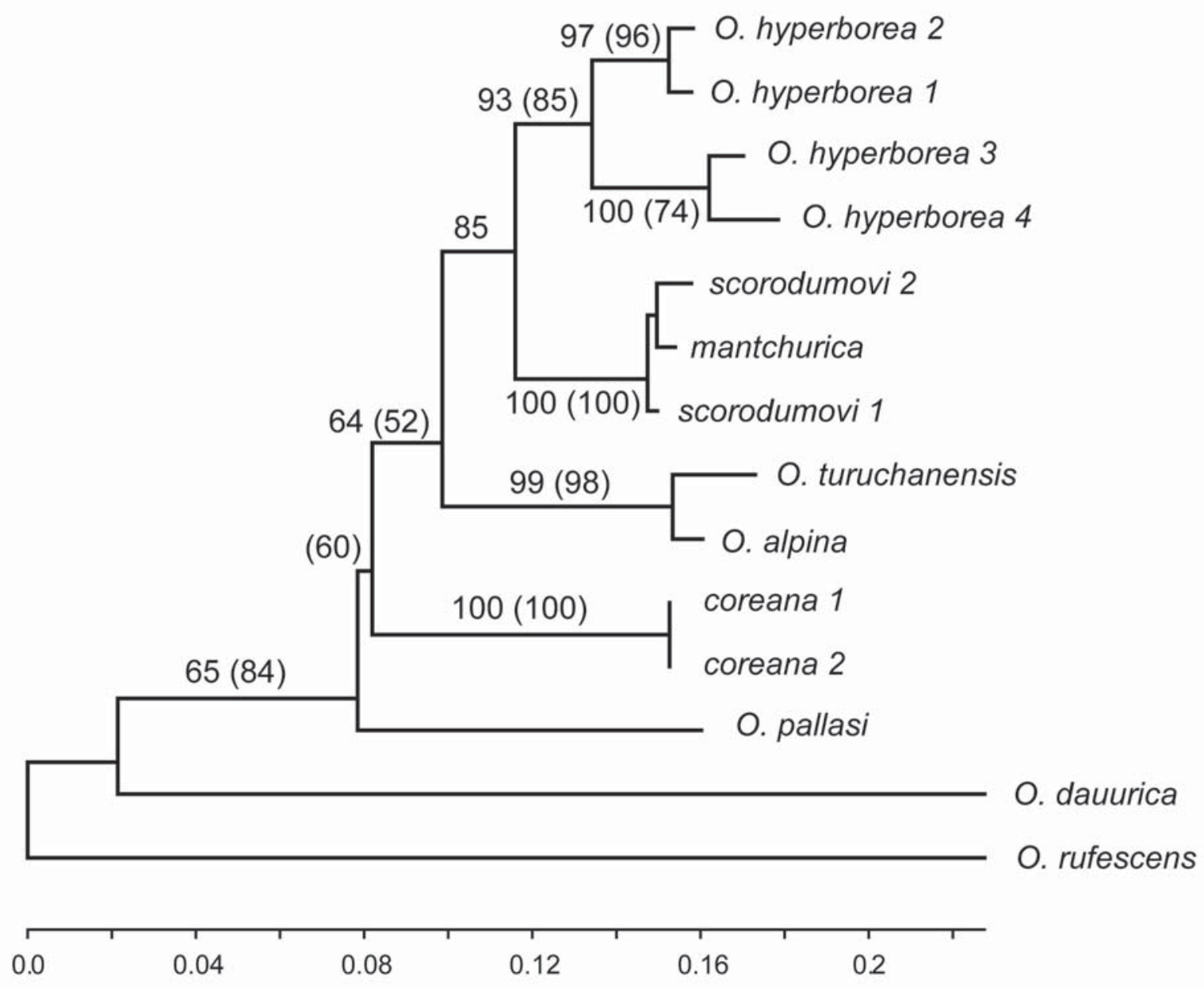

Figure 7. Phylogenetic trees obtained using maximum likelihood. Numbers on branches indicate bootstrap support for the part of gene, corresponding to the length of coreana fragment (in parentheses) and for the full gene. Bootstrap values less than 50 are not shown. For explanations to taxa labels, refer to Appendix.

Terra typica of cinereofusca after the original description is upper Amur River. The location of the type specimens is unknown. The original publication contain dates when R. Maak collected the two specimens which were put into the description of cinereofusca, these are 18 and 20 May of the Julian calendar. These specimens were collected by members of Maak' expedition during exploring the Amur River in 1856 when they rafting from Nerchinsk on Shilka River to lower Amur River. As it was written in the published report of Maak's expedition (Maak, 1859), on the May 18, the explorers collected near the mouth of the spring Tontokoy (Fig. 9) on the left bank of the Shilka River. The fact of bagging a pika is mentioned in the text of report. On May 20, the members of Maak's expedition landed on the meadow lower Anikino River and lower mouth of Grishkina River; these rivers are left tributaries of Shilka River. Yakhontov \& Formozov (1992) also pointed out that Maak collected only on the left bank of Shilka River during those two days. The type locality of the nominal taxon Lagomys hyperboreus cinereofusca Schrenk, 1858 would encompass localities of all the specimens included in the type series because neither holotype nor lectotype were designated (Article 76.1, ICZN, 1999). Therefore, terra typica of cinereofusca should include both the mouth of Tontokoy spring and either lower Anikino River or lower mouth of Grishkina River.

For identification of the taxonomic allocation of the pikas from the terra typica cinereofusca just outlined, we inspected the banks of the Shilka River from UstKurlych village to the mouth of Shilka River. Pikas are practically absent on the left (northern) bank of the Shilka River where the type series of cinereofusca was collected. On the interval between Ust-Kurlych and the mouth of Shilka River talus slopes face the river only four times. There is a little talus in $158 \mathrm{~km}$ from the Shilka River mouth, an extensive area $(23 \mathrm{~km})$ downstream the Anikino River (119 km from the Shilka River mouth), several tali from 39 to $37 \mathrm{~km}$ from the 


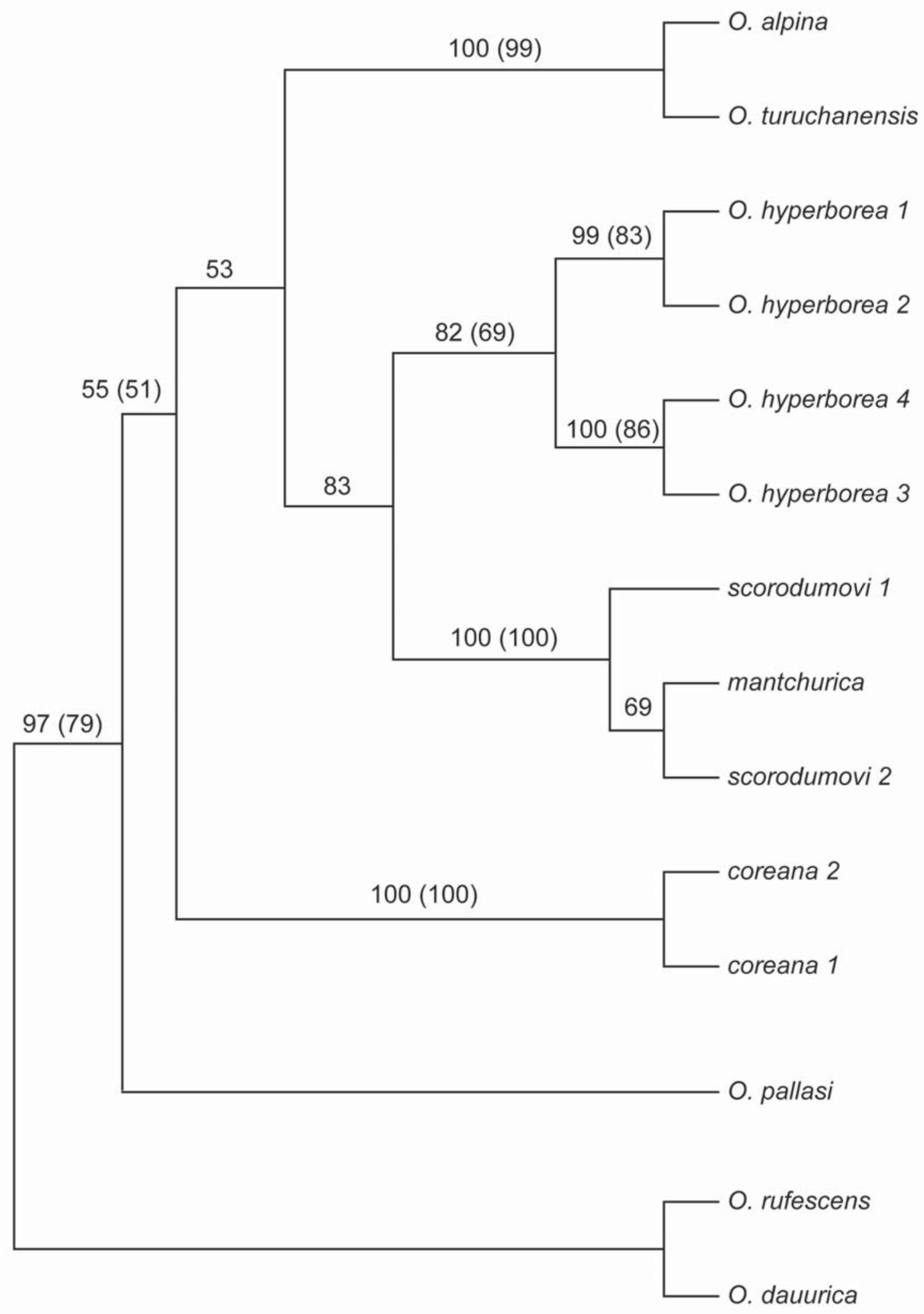

Figure 8. Phylogenetic trees obtained using maximum parsimony. Numbers on branches indicate bootstrap support for the part of gene, corresponding to the length of coreana fragment (in parentheses) and for the full gene. Bootstrap values less than 50 are not shown. For explanations to taxa labels, refer to Appendix. 


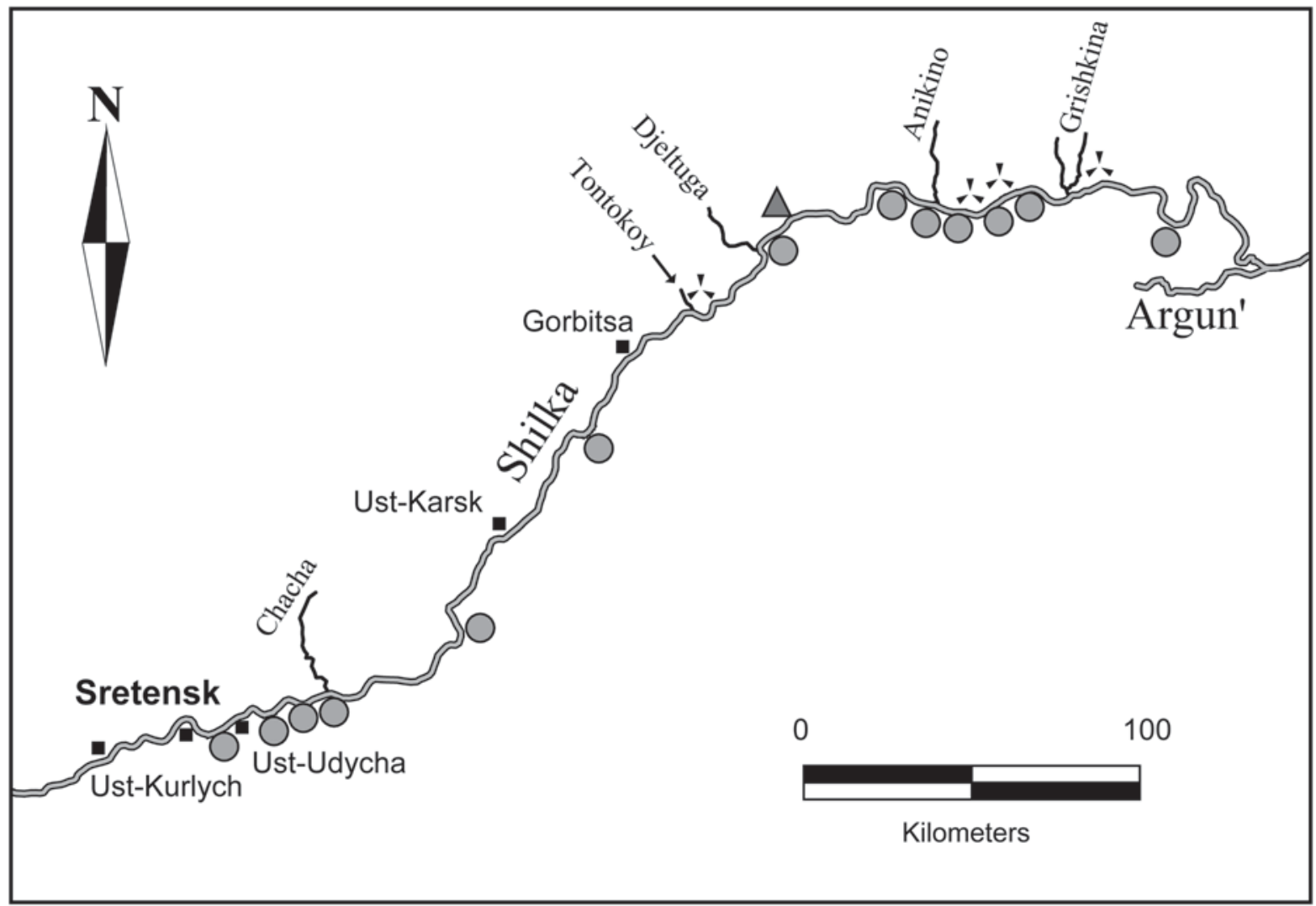

Figure 9. The scheme of the Shilka River. Triangle is a locality where the specimen of $O$. hyperborea was collected. Circles are localities where representatives of the scorodumovi race were collected or their calls were recorded. Tali, visited by Maak 18 and 20 of May 1856 are marked by asterisk.

Shilka River mouth and several tali near $30 \mathrm{~km}$ from the Shilka River mouth. We were unable to detect either pikas or the traces of their activity in the second area, while the other areas are inhabited by pikas with quite small population density. We managed to collect one specimen in the first place. All recorded pikas could be identified as $O$. hyperborea by their calls structure (the deep modulated elements of song and alarm calls were recorded). Estimation of allocation of the specimen by its skull traits to either of the groups of pikas under consideration by discriminant analysis of two teaching samples indicated the following. A probability of its belonging to the group of pikas from the area between Shilka and Argun' rivers was estimated 0.00, and to the species $O$. hyperborea from Transbaikalia was estimated 1.00 .

The remaining area of the left bank of the Shilka River is occupied by steppe (upstream the Gorbitsa village) or meadow (downstream the Gorbitsa) areas. Slopes of the hills are made of fluvial deposits; outcrops are represented by large rocks without rock debris. While inspecting the Tontokoy spring and lower part of Grishkina River, we found small tali, stacked of small stones. We watched no pikas over there but we found very old pika's pellets in a minimal number. Local hunters and fishermen (who know pikas very well due to their abundance on the right bank) stated they had never seen pikas on the left bank. They said that, near Sretensk, Ust-Karsk, on Chacha and Grishkina rivers, the pikas appeared as distantly as $10-20 \mathrm{~km}$ from the bank of Shilka River.

Pikas are quite abundant on the right bank of Shilka River. They en masse inhabit buttes and mossy tali. The most western locality, where pikas calls were recorded was near the abandoned Ust-Udycha village. Stony habitats suitable for pikas can be found periodically downstream the mouth of Dzheltuga River and everywhere after that. In the places where stony habitats do not face the river, they are located no more than at one kilometer from the Shilka' bank.

On the whole the right bank of Shilka River is higher and not suitable for the halts of a loaded raft. Probably this fact was a reason of collecting activity of Maak' expedition only on the left bank.

\section{Discussion}

Pikas from the area between Shilka and Argun' rivers and from Greater and Lesser Khingan mountains form homogeneous group according to all available data. The absence of a sharply defined morphological hiatus between these pikas and other species belonging 
to the alpina-hyperborea group is quite usual for member of the latter. The taxa undistinguished by the skull size are difficult to discriminate in the hyperspace of morphological features, as up to $80 \%$ of overall variation of the skull traits are explained by the size component (Lissovsky, 2003).

The structure of alarm calls is a valuable taxonomic characteristic, which allow to assert that the pikas from the area between Shilka and Argun' rivers and northern Manchuria are distinct from other taxa of alpina-hyperborea group. The unique complicated structure of calls, presence of synchronous biphonations, does not occur in other pikas of that group (Lissovsky, 2005). From our point of view, complexity of the call structure makes unlikely parallel forming of such structure in different groups.

The results of cytochrome b gene study confirm the homogeneity and distinctiveness of pikas from the southeast Transbaikalia and Manchuria. The data on parts of cytochrome $\mathrm{b}$ and cytochrome $\mathrm{c}$ oxidase genes published elsewhere (Lissovsky et al., 2007) allowed to draw attention that genetic distances between the specimen from Manchuria and the scorodumovi race fit well within the range of intraspecific variation in other species. The distance between the clade uniting pikas from the area between Shilka and Argun' rivers and Manchuria, from one hand, and other species, from other hand, allow to suppose the species rank of the discussed taxon (Lissovsky et al., 2007). Our results based on full sequences of cytochrome $b$ gene and using material from topotype of scorodumovi confirm previous conclusions.

To sum up, we suppose that the area between Shilka and Argun' rivers and northern Manchuria is inhabited by only one form of the pikas instead two, as it was stated earlier (Ognev, 1940; Feng \& Zheng, 1985; Sokolov et al., 1994; Niu et al., 2001; Hoffmann \& Smith, 2005). The species rank of this taxon well agrees with bioacoustic data and is supported by its genetic distinctiveness. The degree of morphological differentiation is also corresponds to the degree of interspecific distinction in the alpina-hyperborea group.

The name of this taxon needs some lengthy discussion. Unfortunately we had no possibility to study cytochrome $b$ gene of any specimen from terra typica of mantchurica. However we consider the bioacoustical features is equally reliable in our case. The structure of alarm calls of topotype specimens of both $O$. a. scorodumovi Skalon, 1935 and $O$. h. mantchurica Thomas, 1909 of which the latter has certain priority by date, are identical. So, we consider that both names belong to the taxon under discussion. However, there is another, much earlier name, L. cinereofusca Schrenk, 1858 that has certain concern to the situation under consideration, so it is necessary to clarify its allocation first.

As it was mentioned above, the type series of $\mathrm{ci}$ nereofusca was collected on the left bank of the Shilka River. Only representatives of $O$. hyperborea are known from this bank at present. We could not either collect or even watch the pikas at the type locality of cinereofus- $c a$, but we collected one specimen in the close proximity to that locality and it appeared to be the specimen of $O$. hyperborea. A probability for the pikas to penetrate from the right bank to the left one and to be collected by Maak is assessed by us as extremely low. The tali suitable for the pikas are practically absent on the left bank, which does not allow migrants from the opposite bank, even if they had actually intruded, to gain a foothold here. The absence of fresh traces of the pikas' activity on scarce discovered tali, which are usually kept safe for a long time, supports indirectly such a point of view. Most likely, settlement of the solitary tali of the left bank by pikas is a consequence of high population density in the settlements of O. hyperborea, situated far from the Shilka River bank. Such immigrants probably perish or migrate backward soon.

Thus the name cinereofusca should be allocated to a form of $O$. hyperborea from the left bank of Shilka River. Consequently, the taxon known to occur in the area between Shilka and Argun' rivers and northern Manchuria should be named Ochotona mantchurica Thomas, 1909.

The Korean pikas (or more correctly — pikas from Changbai Shan) are essentially spatially isolated from other pikas from Manchurian region (Fig. 1). Our data on the Korean race are very fragmentary. There are no data on its bioacoustic features. The shape of the single skull from Korea included in the analysis is completely fall into variation of both $O$. mantchurica and $O$. hyperborea. At the same time, mandible height sharply distinguishes representatives of the coreana from $O$. hyperborea. The extent of variation of this character in coreana fits within limits of variation of $O$. mantchuri$c a$. The studied part of cytochrome $\mathrm{b}$ gene is very original. On the basis of genetic analysis, the race coreana takes the basal position in alpina-hyperborea group, though its basal position is supported by relatively low bootstrap values. However, an alternative hypothesis about joining coreana to O. hyperborea or to $O$. mantchurica clades is not supported by these data at any rate; coreana is an outgroup relative to either of these clades with high bootstrap support. Moreover, genetic distance between haplotype of coreana and haplotypes of other species is greater than distance between such species as $O$. alpina and $O$. hyperborea.

The monophyly of the alpina-hyperborea group was shown to have high bootstrap support in case of the cytochrome b gene (Lissovsky et al., 2007). Including of coreana to the tree led to decreasing of bootstrap support. Possibly it supports indirectly the idea about basal position of coreana relatively alpina-hyperborea group.

So we can affirm that the rank of the taxon coreana is comparable with the ranks of other recognized species from alpina-hyperborea group. Taking into account the genetic distinctiveness and isolated range of the Korean pika, we suggest provisionally considering this taxon as a separate species $O$. coreana Allen \& Andrews, 1913 of the alpina-hyperborea group, pend- 
ing on subsequent revision based on more data on bioacoustics, genetic and morphological variation.

ACKNOWLEDGEMENTS. We are grateful to S.P. Yacentuk, N.N. Karpova, S.M. Rastorguev, A.A. Volkov, N.V. Ivanova, N.E. Dokuchaev for the help with molecular matters. A.V. Gorbachev, E.V. Lissovskaya, E.V. Obolenskaya, S.V. Kruskop supported us in the field investigations. Our special thanks are to the administration of Mogoitui District (Mazhiev S.B.) and the Modern University for the Humanities (Mazhieva Z.F.) for the help in the expedition of 2006. We thank G.I. Baranova, E.I. Zholnerovskaya, P. Jenkins, R. Asher, T.A. Sirokhina, N.S. Moskvitina, S.S. Moskvitin, Dong Zheng for the help in collections study. Yan Xie, V.S. Lebedev, I.Ya. Pavlinov helped during preparation of manuscript. The study was partly supported by RFBR (grant \# 0604-49134).

\section{Literature}

Allen J.A. \& Andrews R.C. 1913. Mammals collected in Korea // Bulletin of the American Museum of Natural History. Vol.32. P.427-431.

Bannikov A.G. 1954. [Mammals of the Mongolian People's Republic]. Moscow: Izdatel'stvo Akademii Nauk SSSR. 670 p. [in Russian].

Feng Z. \& Zheng C. 1985. [Studies on the pikas (Genus Ochotona) of China - taxonomic notes and distribution] // Acta Theriologica Sinica. Vol.5. No.4. P.269289 [in Chinese, with English summary].

Hoffmann R.S. \& Smith A.T. 2005. Order Lagomorpha // Wilson D.E. \& Reeder D.M. (eds.). Mammal Species of the World: A Taxonomic and Geographic Reference. Third Edition. Vol.1. Baltimore: Johns Hopkins University Press. P.185-211.

International Code of Zoological Nomenclature (Fourth Edition). 1999. London: International Trust for Zoological Nomenclature. 306 p.

Lissovsky A.A. 2003a. Geographical variation of skull characters in pikas (Ochotona, Lagomorpha) of the alpinahyperborea group // Acta Theriologica. Vol.48. Pt.1. P.11-24.

Lissovsky A.A. 2003b. [The determination of pika species (Ochotona, Lagomorpha) from alpina-hyperborea group] // Orlov V.N. (ed.) The Theriofauna of Russia and Adja- cent Territories. Materials of International Conference 6-7 February 2003. Moskva: Rossiiskaya Akademiya Nauk. P.195-196 [in Russian].

Lissovsky A.A. 2005. [Comparative analysis of the vocalization of pikas (Ochotona, Mammalia) from alpina-hyperborea group] // Byulleten' Moskovskogo Obshchestva Ispytatelei Prirody, Otdel Biologicheskii. Vol.110. No.6. P.12-26 [in Russian, with English summary].

Lissovsky A.A., Ivanova N.V. \& Borisenko A.V. 2007. Molecular phylogenetics and taxonomy of the subgenus Pika (Ochotona, Lagomorpha) // Journal of Mammalogy. Vol.88. No.5. P.1195-1204.

Ma Y., Jin S. \& Li S. 1986. [Fauna Heilongjiangica: Mammalia]. Harbin: Heilongjiang Science \& Technology Press. 520 p. [in Chinese].

Maak R. 1859. [Travel to Amur]. Sankt-Petersburg: Izdanie S.F. Solov'eva. 552 p. [in Russian]

Niu Y., Wei F., Li M. \& Feng Z. 2001. [Current status on taxonomy and distribution of subgenus Pika in China] // Acta Zootaxonomica Sinica. Vol.26. No.3. P.394-400 [in Chinese, with English summary].

Smith A.T., Formozov N.A., Hoffmann R.S., Zheng C. \& Erbajeva M.A. 1990. The Pikas // Chapman J.A. \& Flux J.E.C. (eds.). Rabbits, Hares and Pikas, Status Survey and Conservation Action Plan. Gland, Swizerland: IUCN. P.14-60.

StatSoft Inc. 2001. STATISTICA (data analysis software system), version 6. www.statsoft.com.

Sokolov V.E., Ivanitskaya E.Yu., Gruzdev V.V. \& Heptner V.G. 1994. [Mammals of Russia and Adjacent Regions: Lagomorphs]. Moskva: Nauka. 272 p. [in Russian].

Thomas O. 1909. A collection of mammals from Northern and Central Mantchuria // Annals and Magazine of Natural History, Series 8. Vol.4. No.24. P.500-505.

Yakhontov E.L. \& Formozov N.A. 1992. [Systematic revision of the pika's species complex Ochotona alpina Ochotona hyperborea. 1. Geographic variation in Ochotona alpina] // Vestnik Moskovskogo Universiteta, Seriya Biologicheskaya. T.16. No.1. P.27-33 [in Russian, with English summary].

Yu, N., Zheng C., Zhang Y., \& Li W. 2000. Molecular systematics of pikas (Genus Ochotona) inferred from mitochondrial DNA sequences // Molecular Phylogenetics and Evolution. Vol.16. No.1. P.85-95.

\section{Appendix. The list of pikas findings in Manchurian region. The numbers are corre- sponding to Figure 1; after that locality, source of information and number of studied skulls are shown (in parenthesis). Abbreviations see in text.}

1 - Ling Jiang; IOZ. 2 - Fusong; IOZ. 3 - Garyngneng; ZMMU (1). 4 - Changbai Mt.; IOZ. 5 - Pochong; American Museum of Natural History (New York, USA). 6 - Yichun; IOZ, ZIN, MNB (6). 7 - Wudalianchi; Northwest Plateau Institute of Biology (Xining, China), California Academy of Sciences (San Francisco, USA) - CAS. 8 - Dedu; IOZ. 9 Aihui; IOZ. 10 - Huma; IOZ. 11 - Oroqen Zizhiqi; IOZ. 12 - Ke'erqin Youyi Qianqi; IOZ. 13 - Yalu; ZMMU, CAS (6). 14 - Bukhedu; NHM. 15 - Yador; CAS. 16 - upper Chol River; ZMMU. 17 - Yakeshi; IOZ. 18 - Yitulihe; IOZ. 19 Genhe; IOZ, MNB (12). 20 - mouth of Barangon River; ZMMU. 21 - mouth of Serebryanka River; ZMMU. 22 - mouth of Jeltuga River; ZMMU (1). 23 - Ust-Chernaya; ZMMU (1). 24 - Uleygicha River; ZMMU. 25 - Chachakan River; ZMMU. 26 - Shivki; ZMMU, ZIN (4). 27 - Ushmunskii Golets Mt.; ZMMU (2). 28 - upper Turov River; IGU (2). 29 Kozlovo; ZMMU (2). 30 - Alexadrovskii Zavod; ZMMU, IGU, ZIN, TGU (23). 31 - upper Ker-Khira River; ZMMU (2). 32 - Kaylastuy; ZMMU, IGU, ZIN (6). 33 - Xilinji; HCW (1). 34 - Mohe (Ma et al., 1986). 35 - Holesu (pellets found). 36 - Great Khingan Mts. in Mongolia (Bannikov, 1954). 